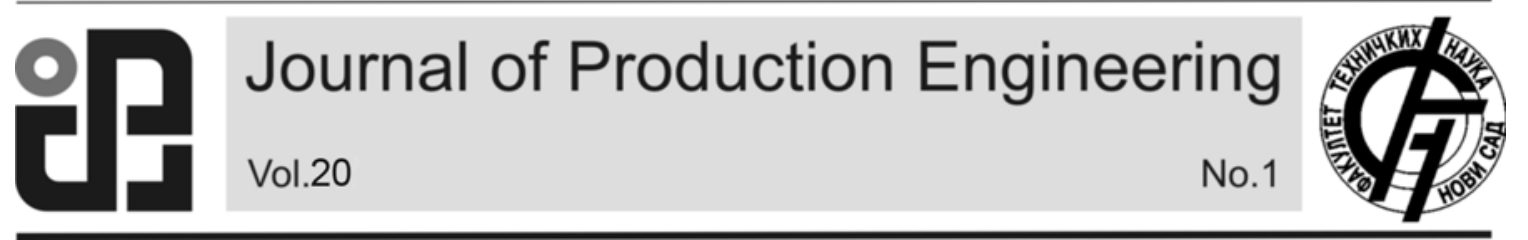

JPE (2017) Vol.20 (1)

Adegbola, J. O., Adedayo, S. M., Ohijeagbon, I. O.

Original Scientific Paper

\title{
DEVELOPMENT OF COW BONE RESIN COMPOSITES AS A FRICTION MATERIAL FOR AUTOMOBILE BRAKING SYSTEMS
}

Received: 06 March 2017 / Accepted: 18 April 2017

\begin{abstract}
Cow bone resin composites as a friction material for automobile breaking systems have been developed. Increasing interfacial bonding was observed as the cow bone particle size decreased from 850 to $250 \mu \mathrm{m}$, resulting in better mechanical properties of brake pads produced with $250 \mu \mathrm{m}$ particle size relative to higher particle sizes investigated. Experimentally produced brake pads with cow bone composites were found to compare favourably with conventional brake pads and those from previous studies; consequently, cow bones particles are suitable replacements for asbestos-free brake pad due to the fact that asbestos dust poses health hazards.
\end{abstract}

Key words: cow bone, breaking system, brake pad composites, asbestos-free

Razvoj kompozita od kravljih kostiju kao frikcioni materijal za kočioni sistem automobila. Razvijeni su od kompozita od kravljih kostiju kao materijala za automobilske kočione sisteme. Povećanje međusobnog vezivanja je primećeno kod obloga od kravlje kosti sa smanjenjnjem veličine čestica od 850 do $250 \mu$ m, što rezultira boljim mehaničkim svojstvima kočionih pločica proizvedenih od veličine $250 \mu \mathrm{m}$ čestica u odnosu na veće veličine ispitivanih čestica. Eksperimentalno je utvrđeno da kočnice proizvedene od kompozita od kravlje kosti su bolje u poređenju sa konvencionalnim kočionim pločicama iz prethodnih studija; prema tome, kočnice od kompozita od kosti krava su odgovarajuća zamene za azbestne kočnice zbog činjenice da azbest prašina postavlja opasnosti po zdravlje.

Ključne reči: kravlje kosti, kočioni sistem, kompozitne obloge, bezazbestne

\section{INTRODUCTION}

Automobile friction pads are of very high significance in braking systems, and are one of the most important safety and performance systems in automobiles. It is essential for all types of vehicles that are equipped with brake disc. Brake pad is a friction material typically attached to a metal backing plates with rivets or high-temperature adhesives facing the brake disc $[1,2]$. Brake pads convert the kinetic energy of a car to thermal energy through friction, thereby fading-out due to operating wear and tear. This makes it one of the most commonly replaced components in the brake system [3]. Components of the brake pad are the lining materials, which are categorized as metallic, semi-metallic, organic and carbon-based, depending on the composition of the constituent elements. Typical formulations consist of different ingredients; however, exact compositions of commercial friction materials are rare in open literature [2, 4]. Ingredients used for brake pads can be grouped as binders, reinforcing fibres, fillers, and frictional additives, based on the major function they perform which includes controlling friction and wear performance. The binder is used to hold the ingredients together, to maintain structural integrity of the brake pads subjected to mechanical and thermal stresses; the structural materials provide the structural reinforcement to the composite matrix; the fillers make up the free volume of the brake lining; and the friction modifiers stabilize the coefficient of friction and wear rates [5].

In the past, asbestos was the standard brake pad material. The composition generally consists of asbestos fibres embedded in polymeric matrix along with other ingredients. It offers good friction qualities, long wear, and low noise. But new materials are being used because of the health hazards of asbestos dust [6]. The use of asbestos fiber is been avoided due to its carcinogenic nature and related asbestos-induced diseases, such as malignancies, asbestosis, lung cancer and pleural mesothelioma [7, 8, 9]. Therefore it is imperative to develop an asbestos-free friction material as brake pads.

Different studies have been carried out in the area of development of asbestos-free brake pad. The use of periwinkle, coconut shell, banana peel, palm kernel shell (PKS) has been developed for asbestos free brake pads materials. The trends in researches are focusing on ways of utilizing either industrial or agricultural wastes as source of raw materials in the industry. [2, 3, 4, 5]. Several benefits have been discovered in employing alternative constituent materials for brake pad production amongst others. Bhane et al. [10] proposed combining two or more materials to determine the tribological properties for brake pad material in order to develop alternatives to conventional materials that would result in composite materials of lower cost, reduced weight and increased life of brake materials. Keskin [11] investigated the use of natural zeolite in brake pad production by adding different amount of zeolite in the mix of other regular ingredients in brake pad production. Zeolite contains silica which gives the pad materials a ceramic like behavior. The friction assessment and screening test (FAST) conducted by 
Keskin [11], shows that the sample with $10 \%$ zeolite rate provided higher friction coefficients, because its wear ratio and standard deviations were considerably lower; while lower value of friction coefficients were obtained for 30 and $35 \%$ zeolite. Similarly, fly ash obtained from power plant in Neyveli Lignite Corporation was used by Vijay et al. [12] to incorporate $50 \%$ wt of fly ash particles in automotive brake lining friction composites; and developed brake lining composites was found to exhibit consistent coefficients of friction in the range of 0.3-0.4, and wear rates lower than $12 \%$ wt. Also, the selection and production of composite brake pad with varied constituent's composition was investigated by DanAsabe et al. [13] to determine the tensile, compressive, hardness, impact, wear and corrosion to ascertain composition with the optimum property compared with a commercial Honda brake pad (Enuco) model widely used in Nigeria. Asabe et al. [13] observed that higher percentage of grounded coconut shell powder induces brittleness, and lower percentage produced higher breaking strength and lower wear rate.

Cow bones constitute a waste in developing countries. In the rearing and consumption of cows, cow meat is considered a major source of protein, while cow bone is bio-degradable, free from asbestos molecules, ecologically friendly and consists of high strength. Consumption of cow meat on a daily basis is very high and as a result most of the cow bones are discarded as waste in most abattoirs in Nigeria [14]. Development of a sustainable raw material for production of brake pads will contribute in addressing global climatic problems and several socioeconomic related issues. This work is aimed at developing a new asbestos-free friction brake pad which is environmentally friendly using cow bones as the base material.

\section{EXPERIMENTAL PROCEDURES}

\subsection{Materials and equipment}

The materials and equipment used in this study are: phenolic resin (phenol formaldehyde), cow bones, engine oil (SAE 20W/50), water, designed brake pad mould, band heater, digital weighing balance, a set of sieves, digital weighing machine, bunsen burner, polisher machine with load, inclined planes and computerized metallurgical microscope. The chemical compositions of cow bones comprises of $23.326 \%$ calcium and $2.602 \%$ Iron [15].

\subsection{Production of brake pad composites}

Cow bones as sourced from the abattoir in Ilorin, Nigeria was washed, cleaned and sun dried for 21 days, followed by oven drying at $105^{\circ} \mathrm{C}$ for 5 hours until the moisture and oil content was almost completely eliminated. The dried bones were then charged into a hammer mill that reduces the size of the bones into smaller particle sizes [16]. The product was transferred into a set of sieve of; $+850 \mu \mathrm{m},+500 \mu \mathrm{m},+250 \mu \mathrm{m}$. While the oversize of $+850 \mu \mathrm{m}$ was returned or recycled for regrinding until it passes through the sieves.

Grinded bones with particle sizes of $250 \mu \mathrm{m}, 500$ $\mu \mathrm{m}$ and $850 \mu \mathrm{m}$, were mixed with the $35 \%$ wt phenolic resin. Digital weighing balance was used for precision weight measurements. Twenty five (25) test samples from each of the sieve size were then produced. Each composition was blended homogeneously. The mixed samples were then transferred to the designed mould kept at a temperature of $150^{\circ} \mathrm{C}$. Mixtures were compacted at a pressure of $15 \mathrm{MPa}$ for 2 minutes using a $1560 \mathrm{KN}$ unaxial, hydraulic compression machine. Mould surface was polished with mould-releasing agent prior to loading to ease removal of produced composite from the mould. At the end of the hotpressing process, the composite brake pad samples were taken out of the moulds, allowed to cool at room temperature, and cured in an oven at a temperature of $120^{\circ} \mathrm{C}$ for 8 hours $[16,17,18]$.

\subsection{Physical characteristics and mechanical tests procedure}

\subsubsection{Brinell hardness test}

The resistance of the composites to indentation was examined through the hardness testing equipment based on BS240. A Tensometer was used to press a hardened steel ball with diameter D into a test specimen. Based on ASTM specification, a $10 \mathrm{~mm}$ diameter steel ball was used, and the load applied $\mathrm{P}$ was kept stable at $3000 \mathrm{kgf}$. The diameter of the indentation $\mathrm{d}$ was measured along two perpendicular directions, using an optical micrometer screw gauge. The mean value was taken and incorporated into equation 1 to obtain the Brinell Hardness Number (BHN) [5].

$$
B H N=2 P \div \pi D\left(D-\sqrt{D^{2}-d^{2}}\right)
$$

$\mathrm{P}$ is the load applied, D is the diameter of hardened steel ball into a test specimen and $d$ is the diameter of indentation.

\subsubsection{Coefficient of friction}

Each sample of produced brake pads with different sieve sizes was placed on inclined plane of known angle and a $90^{\circ}$ wedge. Wedge of a known height was positioned and varied to increase the angle of inclination until specimen was just about to slide down the plane. Equation 2 was used to calculate resulting coefficient of static friction [5].

$$
\mu=\tan \theta
$$

where, $\theta$ is an angle of repose at instant of sliding

\subsubsection{Water and oil absorption test}

The water and oil (SAE 20W/50) absorption of the samples were determined by soaking the samples in water and oil for 24 hours. The initial weight of each specimen was taken and recorded as $\mathrm{W}_{0}$ before soaking in engine oil and water. After 24 hours, specimens were brought out of oil and water, thoroughly cleaned to remove water and oil on surfaces, reweighed and recorded as $\mathrm{W}_{1}$. Differences in initial and final weights for each specimen were then used to determine absorption rate $[2,4-5]$.

$$
\text { Absorption rate }(\%)=\frac{W_{1}-W_{0}}{W_{0}} \times 100 \%
$$




\subsubsection{Flame resistance test}

The flame resistance of the samples was carried out by placing produced samples on wire gauze positioned directly on the blue flame of a Bunsen burner. The sample weight before and after burning was taken after 10 minutes and was used in obtaining the percentage of flame resistance $[2,3,4,5]$.

\subsubsection{Wear characteristics}

The wear characteristics were determined using a polisher machine with load. The set up was similar to the concept of the pin-on-disc test. The tested samples have a dimension of $40 \mathrm{~mm}$ in diameter and $10 \mathrm{~mm}$ in height. The samples were placed in the rotating wheel of the polisher machine. All tests were conducted at room temperature. The pin with a $8 \mathrm{~mm}$ diameter with a load of $10 \mathrm{~N}$ was placed on each sample rotating with a speed of 100rpm. The samples were weighed before and after testing to determine weight loss within an accuracy of $0.0001 \mathrm{mg}$. Wear rates was determined using equation 4 .

$$
\text { Wear rate }=\frac{W_{a}-W_{b}}{S}
$$

where, $\mathrm{W}_{\mathrm{a}}$ is initial weight and $\mathrm{W}_{\mathrm{b}}$ is the final weight after wear.

\subsubsection{Density test}

The ASTM standard D792-00 specification was used to calculate the density of the composite specimens. A clean sample is weighed accurately in air using an electronic pocket scale model: EHA901, and then suspended in water. The weight of the sample when suspended in water was determined, and the volume of the sample was determined from the effect of displacement by water [19].

$$
\text { Density, } \rho=\frac{M}{V}
$$

where, $\mathrm{M}$ is the mass of test piece $(\mathrm{g})$ and $\mathrm{V}$ is the measuring volume of test piece $\left(\mathrm{cm}^{3}\right)$ by liquid displacement method.

\subsubsection{Morphological test}

The microstructural examination of the samples was carried out by grinding the samples using 200, 300, 400, and 600 grit papers respectively. Dry polishing was then carried out on the samples and the internal structures were viewed under the computerized metallurgical microscope [2].

\section{RESULTS AND DISCUSSIONS}

\subsection{Results}

The friction brake pads developed were subjected to various tests; these are hardness, water and oil absorption, wear characteristics, flame resistance, density and microstructural examination. The results of tests carried out were analyzed to determine the potential of the asbestos free brake pad for application as a brake pad material. The test results were compared with corresponding properties of conventional asbestos based brake pads and from previous studies. The results made clear the effect of the physical and mechanical constituent properties of the developed friction material considering the manufacturing procedure employed.

\subsection{Brinnel hardness test}

Figure 1 shows the result of the Brinell hardness test with three different sieve size particles in comparison with three other brake pad products from previous studies [2]. The sample with $250 \mu \mathrm{m}$ sieve grade has the highest hardness value of $102.62 \mathrm{BHN}$. A gradual drop in hardness was observed in the samples with higher sieve grades $(500 \mu \mathrm{m}, 850 \mu \mathrm{m})$. The high hardness observed for the $250 \mu \mathrm{m}$ sieve grade was as a result of reduced particle size of cow bones which results in increase in contact surface area and subsequent increase in bonding ability with the resin. This is lower than hardness value of $100 \mu \mathrm{m}$ PKS based of $125 \mathrm{BHN}$. It is slightly higher than commercial brake pad (asbestos based) (101BHN) and bagasse based $(100.5 \mathrm{BHN})$ brake pad [2, 4, 5]. The PKS based showed a higher hardness value which may be as a result of the $20 \%$ binder and lower sieve size of $100 \mu \mathrm{m}$ and other materials used in its formulation compared to the $35 \%$ used for the formulation of produced cow bone based brake pad. This results in increasing bonding and glue line between the brake pad materials thereby improving its hardness properties. It can be inferred from the result trend that smaller bone particles sizes enhances the hardness value.

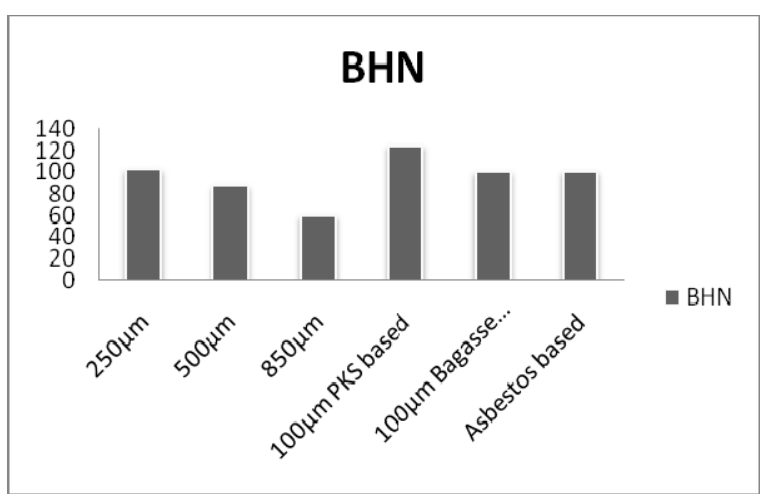

Fig. 1. Comparison of hardness of developed friction brake pad

\subsection{Coefficient of friction $(\boldsymbol{\mu})$}

Figure 2 presents the results of the average coefficients of friction for each of the sieve size cow bone-based brake pad compositions with the parameters used. The coefficient of friction decreased as sieve sizes of the cow bones increased in each composition. The coefficient of friction of each produced sieve sizes compares favourably with that of conventional brake pad obtained by standard method $[2,5]$. The value for brake pad with $250 \mu \mathrm{m}$ cow bones sieve sizes was the highest with friction coefficient of 0.42 while $500 \mu \mathrm{m}$ and $850 \mu \mathrm{m}$ sieve sizes had 0.39 and 0.36 respectively. The coefficient of friction of conventional brake pad is usually in the range $0.3-0.4$ [5]. It can be concluded, that the developed brake pad satisfy the requirement with $250 \mu \mathrm{m}$ excelling above the range for conventional brake pads. By comparison, friction coefficient of the developed brake pad $250 \mu \mathrm{m}$, $500 \mu \mathrm{m}$ and $850 \mu \mathrm{m}$ varied above the mean values of 
that of commercial brake pad $(0.35$.) by $20 \%, 11.43 \%$ and $2.86 \%$ respectively. The friction coefficient of developed pad of $250 \mu \mathrm{m}$ was slightly higher than those obtained in previous studies [2, 4, 5, 19].

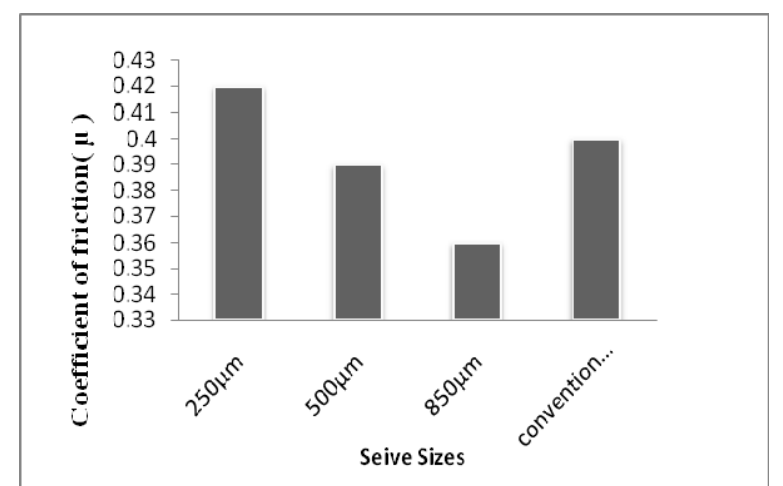

Fig. 2. Coefficient of friction $(\mu)$ of different sieve sizes

\subsection{Water and oil absorption test}

Figure 3 shows the test results obtained from the experiment after 24 hours. The water and oil adsorbent property of the developed brake pad tends to increase as the sieve sizes increase from $250 \mu \mathrm{m}$ to $850 \mu \mathrm{m}$ in the formulation. This increased water and oil absorption rate was due to the decreased interfacial bonding between binder and filler particle which results in increased porosity. The result compared favourably with that of the earlier observation of Aigbodion et al. [2] of bagasse based brake pad. The water absorption value for the produced brake pad was $5.07 \%$ and this value compares favourably with that of optimum formulation brake pad PKS and bagasse based which had water absorption values of $5.03 \%$ and $3.48 \%$ respectively as shown in figure 3 . The commercial brake (asbestos based) with a water absorption value of $0.9 \%[1,2,5]$ showed an extremely better water absorption property than the experimentally produced brake pad. The oil absorption value for the produced brake pad was $1.3 \%$ and this value compares with that of optimum formulation brake pad PKS and bagasse based which had oil absorption values of $0.44 \%$ and $1.11 \%$ respectively as shown in figure 3 . However the commercial brake (asbestos based) with an oil absorption value of $0.3 \%[1,2,5]$ showed an extremely better oil absorption properties as well, than the produced brake pad. The brake pad absorption rate could be improved if other additives are added with lower sieve sizes.

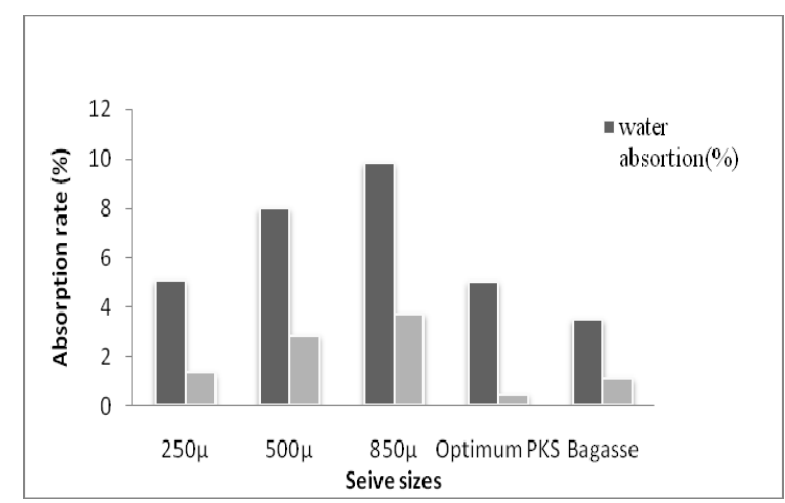

Fig. 3. Water and oil Absorbent properties of developed brake pad

\subsection{Flame resistance}

A good brake pad should possess good resistance to high heat and temperature $[2,6]$. From the test performed, flame resistance test after 10 minutes showed that the produced brake pad of sieve size $250 \mu \mathrm{m}$ is charred with only $12 \%$ ash. This makes it of better heat and temperature resistance than PKS-based and bagasse-based brake pad with $46 \%$ and $34 \%$ ash content respectively $[1,5]$. Figure 4 shows the flame resistant results obtained from the experiment after 10mins heating time.

It can also be inferred from the tests that the developed brake pad competes favourably with the conventional brake pads with small variance of $4 \%$. This implies that, if lower bone particle sizes is used it will result in better resistance to heat and temperature. The percentage charred properties increased as the sieve grade increases which can be attributed to the increase in pores as sieve size increases. These results are at par with earlier observations $[1,2,3,4,5]$.

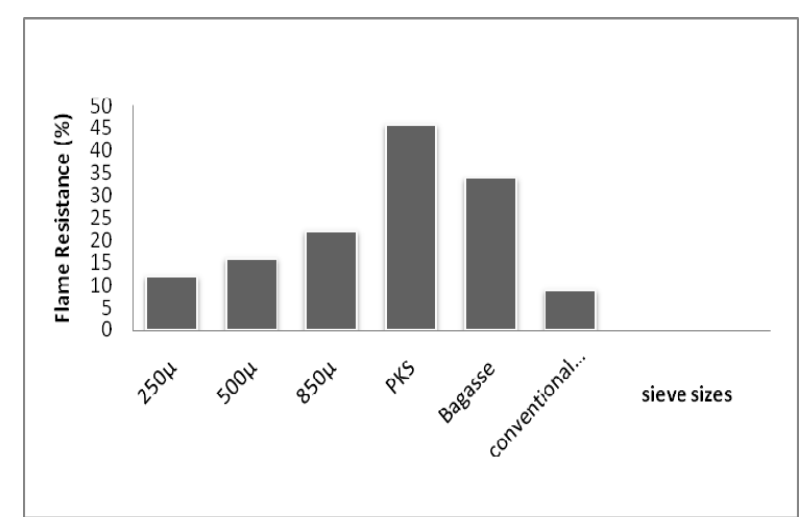

Fig. 4. Flame resistance of developed braked with others

\subsection{Density test}

Figure 5 shows the variation of density with bone particle sizes. The density decreased as the bone particle sizes of the developed brake pad increased. The increase in density can be attributed to the decrease in particle sizes, that is, increased packing of cow bone particle. The $250 \mu \mathrm{m}$ has the highest density which is as a result of closer packing of cow bone particles creating more homogeneity in the entire phase of the composite body [5].

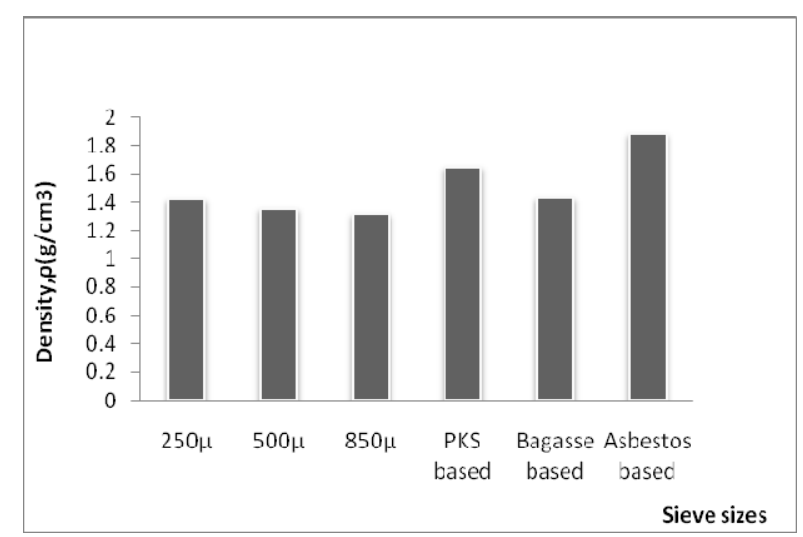

Fig. 5. Densities of developed brake pad with other brake pads 
The density results were determined and plotted against the compositions of specimens as shown in figure 5 where density decreased as the sieve size of the developed brake pad increased. This value compares favorably with that of optimum formulation brake pad PKS and bagasse based which had water absorption values of 1.65 and 1.43 respectively as shown in figure 5. Though, the weight/volume of specimens was less than that of commercial brake pad $\left(1.890 \mathrm{~g} / \mathrm{cm}^{3}\right)$ however is in par with standard $[1,2,5]$. The density of each developed auto-system friction brake pad of $250 \mu \mathrm{m}, 500 \mu \mathrm{m}$ and $850 \mu \mathrm{m}$ varied from that of the conventional brake pad by $24.77 \%, 28.22 \%$ and $30.31 \%$ respectively.

\subsection{Wear characteristics}

Figure 6 shows the wear of the developed brake pad samples. The wear increases as the particles size of the cow bone increased from $250-850 \mu \mathrm{m}$. The lower wear rate at lower particle size of the brake pad formulation can be attributed to interfacial bond between the particle and the resin, which reduces the possibility of a particle pull out. This observation is at par with the work of Aigbodion et al [2]. From previous studies it was observed that, increase in pores formed between particles sizes, significantly affected wear characteristics [20].

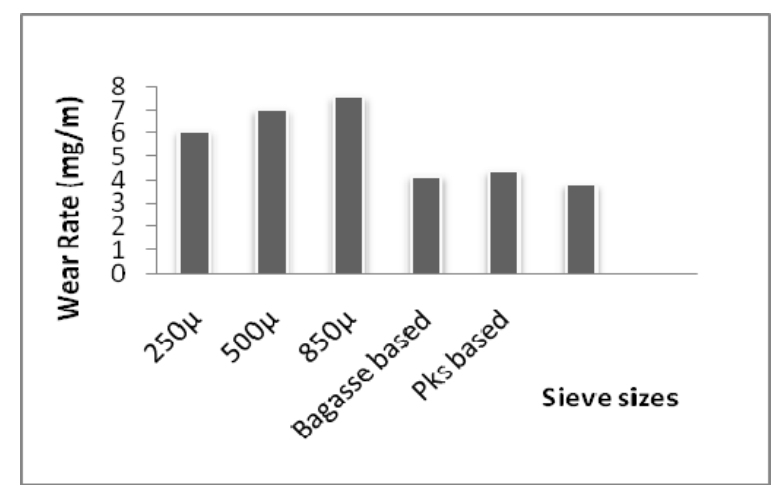

Fig. 6. Wear rate of developed brake pad and other allied products

\subsection{Microstructure analysis}

Figures 7-9 show the microstructure of $250 \mu \mathrm{m}$, $500 \mu \mathrm{m}$ and $850 \mu \mathrm{m}$ bone particle sizes. Figure 7 shows an almost even dark region of resin and white region of cow bones of $250 \mu \mathrm{m}$. Figure 8 Shows slight uniform dark region of resin and white region of cow bone region.

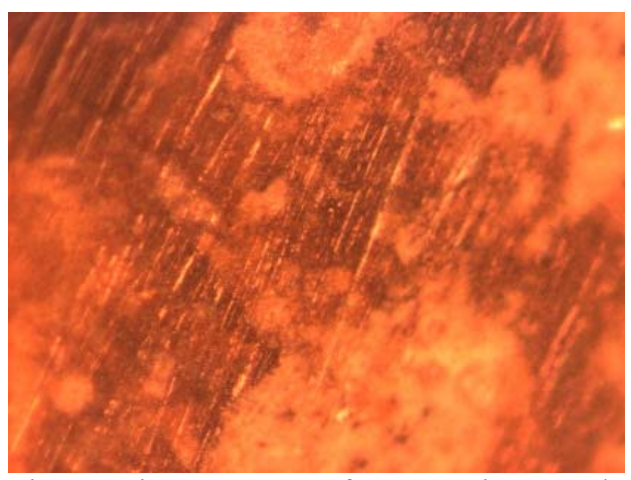

Fig. 7. Microstructure of $250 \mu \mathrm{m}$ sieve grade sample(X100).

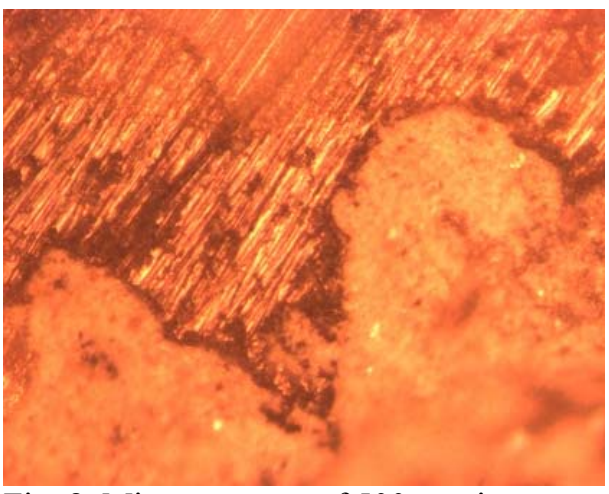

Fig. 8. Microstructure of $500 \mu \mathrm{m}$ sieve sample(X100).

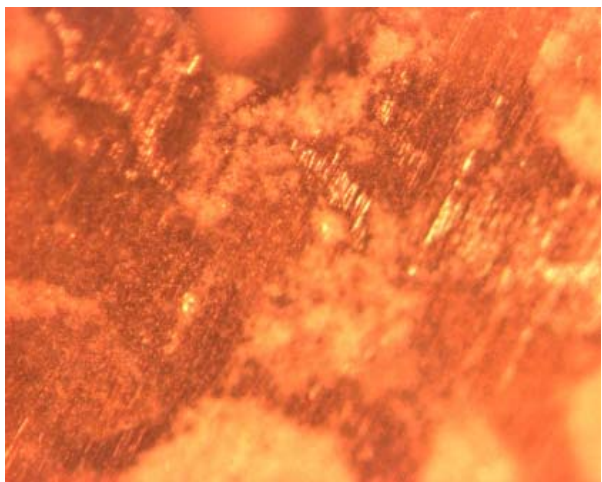

Fig. 9. Microstructure of $850 \mu \mathrm{m}$ sieve grade sample(X100).

From the microstructure there is more uniform distribution of the resin with the cow bone as the particles size of the cow bones decreased. This is as a result of proper bonding between the cow bone particles and the resin as the sieve grade decrease and also closer inter-packing distance. It can be predicted that if lower bone particle sizes are used, the interpacking distance will also reduce thereby giving better properties.

The result of this study indicates that samples containing $250 \mu \mathrm{m}$ ( $65 \%$ cow bones- $35 \%$ resin) gave better properties than other samples tested. Hence, the lower the sieve grades of cow bones, the better the properties. The $250 \mu \mathrm{m}$ sieve size results were compared with those of commercial brake pad (asbestos based) and optimum formulation laboratory brake pad (Palm Kernel Shell based (PKS) from previous studies $[1,5]$.

\section{CONCLUSION}

Cow bone particle $(65 \%$ cow bone partcles- $35 \%$ phenolic resin) composite material friction brake pad was successfully developed using a compressive moulding process. There was increasing interfacial bonding as the cow bone particle size decreases from 850 to $250 \mu \mathrm{m}$. The $250 \mu \mathrm{m}$ cow bone particle size gave better properties relative to higher particle sizes studied. The wear rate increases with increasing cow bone particle sizes. The co-efficient of friction obtained were within the recommended standard for automobile friction brake pad. Hardness and densities of the produced samples were seen to be decreasing with increase in cow bone particle sizes, while oil, water 
soak, wear rate and percentage charred increased as cow bone particle size increased. It is hereby recommended that produced brake pad from cow bone composites be coated with a hydrophobic substance like paraffin wax to reduce its water absorption value, thereby greatly improving the physical stability of the produced brake pads. The results of this study indicates that cow bone particles composite materials can be used as a suitable replacement for asbestos in the manufacturing of brake pads.

\section{REFERENCES}

[1] Deepika, K., Bhaskar, R.C., Ramana, R.D.: Fabrication and performance evaluation of composite material for wear resistance application, International Journal of Engineering Science and Innovative Technology, 2 (6), pp. 6670,2013

[2] Aigbodion, V.S., Akadike, U., Hassan, S.B., Asuke, F., Agunsoye, J.O.: Development of asbestos free brake pad using bagasse, Tribology in Industry, 32 (1), pp.12-17, 2010.

[3] Erjavec, J.: Automotive technology: a system approach, 5th Edition, Cengage Learning, USA, pp.1424-1426, 2010.

[4] Idris, U.D., Aigbodion, V.S., Abubakar, I.J., Nwoye, C.I.: Eco-friendly asbestos free brake-pad: using banana peels, Journal of King Saud University-Engineering Sciences, 27, pp.185-192, 2013.

[5] Elakhame, Z.U., Alhassan, O.A., Samuel, A.E.: Development and production of brake pads from palm kernel shell composites, International Journal of Scientific and Engineering Research, 5 (10), pp. 734-744, 2014.

[6] Maleque, M.A., Atiqah, A., Talib, R.J., Zahurin, H.: New natural fibre reinforced aluminium composite for automotive brake pad, International Journal of Mechanical and Materials Engineering (IJMME), 7 (2), pp. 166-170, 2012.

[7] Doll, W., Peto, J.: Effects on health of exposure to asbestos, Health and Safety Commission, HSE Books, 1996.

[8] Kim, S.J., Williams, D., Cheresh, P. Kamp, D.W.: Asbestos-induced gastrointestinal cancer: an update, Gastrointestinal and Digestive System, 3 (3), pp. 1-6, 2013. http://dx.doi.org/10.4172/2161069X.1000135

[9] Olabisi, A.I., Adam, A.N., Okechukwu, O.M.: Development and assessment of composite brake pad using pulverized cocoa beans shells filler, International Journal of Materials Science and Applications, 5 (2), pp. 66-78, 2016. doi: 10.11648/j.ijmsa.20160502.16

[10]Bhane, A.B., Kharde, R.R., Honrao, V.P: Investigation of tribological properties for brake pad material: a review, International Journal of Emerging Technology and Advanced Engineering, 4 (9), pp. 530-532, 2014.

[11] Keskin, A.: Investigation of using natural zeolite in brake pad, Scientific Research and Essays, 6 (23), pp. 4893-4904, 2011. DOI: 10.5897/SRE10.1072
[12] Vijay, R., Kumar, S.R., Satish, V., Thiyagarajan, V., Subramaniam, L.: Development and testing of asbestos free brake pad material, International Journal of Manufacturing Science and Engineering, International Science Press, 2 (2), pp. 57-63, 2011.

[13] Dan-Asabe, B., Madakson, P.B., Manji, J.: Material selection and production of a coldworked composite brake pad, World $\mathrm{J}$ of Engineering and Pure and Applied Sci., 2 (3), pp. 92-97, 2012.

[14] Oladele, I.O., Adewole, T.A.: Influence of cow bone particle size distribution on the mechanical properties of cow bone-reinforced polyester composites, Biotechnology Research International, Hindawi Publishing Corporation, Article 725396, pp.1-5, 2013.

[15] Agunsoye, J.O., Talabi, S.I., Awe, O., Kelechi, H.: Mechanical properties and tribological behaviour of recycled polyethylene/cow bone particulate composite, Journal of Materials Science Research, 2 (2), pp. 42-50, 2013.

[16] Dagwa, I.M., Ibhadode, A.O.: Determination of optimum manufacturing conditions for asbestosfree brake pad using Taguchi method, Nigerian Journal of Engineering Research and Development, Basade Publishing Press Ondo, Nigeria, 5 (4), pp. 1-8, 2006.

[17] Mathur, R.B., Thiyagarajan, P., Dhami, T.L.: Controlling the hardness and tribological behaviour of non - asbestos brake lining materials for automobiles, Journal of Carbon Science, 5 (1), pp. 6-11, 2004.

[18] Kim, S.J., Kim, K.S., Jang, H.: Optimization of manufacturing parameters for brake lining using Taguchi method, Journal of Material Processing Technology, no.136, 2003, pp. 202-208, 2003.

[19] Nuhu, A.A., I.O. Adeyemi, I.O.: Development and evaluation of maize husks (asbestos-free) based brake pad, Industrial Engineering Letters, 5 (2), pp. 67-80, 2015.

[20] Yakubu, A.S., Amaren, S.G., Yawas, D.S.: Evaluation of the wear and thermal properties of asbestos free brake pad using periwinkles shell particles, Usak University Journal of Material Sciences, 1, pp. 99-108, 2013.

Authors: Professor Segun M. Adedayo PhD, Senior Lecturer Idehai O. Ohijeagbon PhD, James O. Adegbola M.Eng. University of Ilorin, Department of Mechanical Engineering, P.M.B. 1515, Ilorin, Nigeria, Phone: 234-7030092411,

E-mail: adyos1@yahoo.com, idehaiohi@yahoo.com, adegbolajames01@gmail.com 